\title{
Dyeing of protein fabrics exploring locally available weed plants
}

\author{
Babita Bhandari* and Anita Rani \\ Department of Clothing and Textiles, College of Home Science, G.B.Pant University of Agriculture \& Technology, \\ Pantnagar-263145 (Uttarakhand), INDIA \\ *Corresponding author. E-mail: babita.bhandari55555@gmail.com
}

Received: November 8, 2017; Revised received: January 12, 2018; Accepted: February 22, 2018

\begin{abstract}
In the present study weed plants i.e. Lantana camara, Solanum nigrum, Eupatorium adenophorum, Tridax procumbens, Parthenium histerophorus, Sida acuta, Ipomea cairica, Rumex nepalensis, Eclipta prostrate, Girardinia diversifolia, Erigeron bellidioides, Bidens pilosa and Athatoda vasica available in hilly as well as Tarai regions of Uttarakhand were collected, dried and powdered. The powdered dye materialswere extracted in distilled water. Subsequently dyeing of wool and silk fabrics was carried out. It was found that various plants like E. adenophorum, $R$. nepalensis and B. pilosa gave acceptable colour on silk and wool fabric. Therefore some weed plants can be used for textile dyeing which will provide a scope for management of weed plants as well as safety of other useful indigenous plants.
\end{abstract}

Keywords: Dye extraction, Natural dyeing, Protein fabrics, Textiles, Weed plants

\section{INTRODUCTION}

Natural dyes were extensively used long before synthetic dyes came into existence. Natural dyes have many advantages over synthetic dyes like unique subtle hues from renewable resources and low environmental impact. In a study it was found that the BOD value of effluent generated from natural dyes was 40 $85 \mathrm{mg} / \mathrm{L}$ which is much below the limit of $100 \mathrm{mg} / \mathrm{L}$ prescribed by Central Pollution Control Board, Government of India (Henriques and Shankar, 2007). Dumitrescu et al., (2004) had emphasized the necessity of using natural dyes as an approach for reducing pollution owing to large scale use of synthetic dyes and to increase the acceptance of eco-friendly products in the market. Today consumers are willing to pay high for the eco-friendly products as way of protecting nature. Natural dyes are claimed to be clinically safer due to non-carcinogenic and biodegradable nature. Natural dyes are gaining demand in international market which is about 10,000 tons, which is equivalent to $1 \%$ of the world synthetic dye consumption (Sachan and Kapoor, 2007).

Moreover, natural dyeing practices create employment avenues in rural area which also helps in promoting rural entrepreneurship (Bhuyan et al., 2016). Some interested practitioners are using natural dyes for exclusive dyeing of handicrafts and handloom textiles at small scale in an attempt to produce green textiles. Various NGOs like Avani in Kumaun region, Appropriate Technology India in Garhwal region of Uttarakhand are using natural dyes to dye handloom products and sell their products at both domestic and international markets. Such efforts not only encourage the people to go for green products but also help in sustainable development of the area by taking care of social, economic and ecological aspects simultaneously. Weed plants are the undesirable plant in any area. These plants can grow aggressively creating a threat for other desirable flora in a particular area. Weeds deplete large quantities of mineral nutrients and moisture more efficiently than the crop plants and thrive better over the crops in drought conditions. They shade the crop seedlings and occupy space where crop plants should grow their roots. Weeds have higher requirements of nutrients than crop plants; they grow faster and absorb nutrients more efficiently and thus limiting the availability of the same to crop plants (Murty and Venkaiah, 2011).

Weed plants such as Chromolaena odorata, Lantana camara, Parthenium histerophorus and Ageratum conyzoides have made severe ecological losses in India (Tripathi et al.; 1981; Annapurna and Singh, 2003; Raghubanshi et al., 2005; Negi and Hajra, 2007; Reddy, 2008). Weeds were reported to cause up to onethird of the total losses in yield, besides impairing quality of produce and causing health and environmental hazards (DWSR, 2013).Like other plants these plants also possess phyto-chemicals like tannin, phenols and colouring components in varying amount. Using weed plants for dye extraction will not only help in providing an alternative source of dye to local textile dyers but also reduce the invasion of weed plants in food and cash crops. 
In view of advantages of using natural dyes and unutilized natural resources like weed plants in the cropland and along roadside, railway tracks, an attempt was made in present study to explore the dyeability of various locallyavailable plants like L. camara, Solanum nigrum, Eupatorium adenophorum, Tridax procumbens, P. histerophorus, Sida acuta, Ipomea cairica, Rumex nepalensis, Eclipta prostrate, Girardinia diversifolia, Erigeron bellidioides, Bidens pilosa and Athatoda vasica.

\section{MATERIALS AND METHODS}

In this study, natural protein fabrics i.e., silk and wool were selected andwere prepared for dyeing through degumming and scouring respectively using $5 \mathrm{~g} / \mathrm{L}$ non ionic detergent at $50^{\circ} \mathrm{C}$ for 1 hour. Different weed plants i.e. L. camara, S. nigrum, E. adenophorum, $T$. procumbens, P. histerophorus, S. acuta, I. cairica, $R$. nepalensis, E. prostrate, G. diversifolia, E. bellidioides, B. pilosa and A. vasica available around the cropland, in waste lands, along roadside were collected from Pantnagar and hills of Uttarakhand (district - Pithoragarh). Leaves of the plants and roots of different plants were shade dried and powdered. The powered dye materials were extracted in distilled water at 90$95^{\circ} \mathrm{C}$ for 60 minutes. Subsequently dyeing of prepared silk and wool fabrics was carried out at $85-90^{\circ} \mathrm{C}$ for 60 minutes.Assessment of the dyed fabrics was done in terms of colour strength, wash and light fastness properties.Colour strength of the fabric was observed using spectrophotometer SS5100A (Kumaresanet al, 2013). Wash and light fastness tests were carried out following IS: 3361-1979 and IS: 2454-1985 methods respectively using launder-o-meter and light fastness tester (Trotman, 1993)

\section{RESULTS AND DISCUSSION}

Table 1 shows the colour strength, wash fastness and light fastness of wool fabrics dyed with different weed plant dye extracts. It is evident from Table 1 that maximum colour strength $(\mathrm{K} / \mathrm{S})$ was observed on wool with dye extracted from $A$. adenophora(21.55)followed by wool dyed with extract of R.nepalensis(12.88). Due to the havoc caused by invasion of ageratina plant, efforts have been made to utilize it for dye extraction by various researchers previously (Bansal and Sood 2001, Sharma et al., 2007andChairat et al., 2011). Some NGOs in Uttarakhand are also using it for dyeing of textiles. It was reported that roots of $R$. nepalensis was also used by Bhotiya ethnic groups in Uttarakhand to prepare natural dyes (Kala, 2002). Hence there is a scope of detailed study regarding optimization of $R$. nepalensis and $A$. adenophoraplant material.

The wool samples dyed with extract of three plant dye sources exhibited colour strength in narrow range viz1 1.35 by $L$. camara, 11.25 by $A$. vasicaand 11.17 by E. bellidioides. These were followed bydyed wool samples of E. prostrate (10.47), S. nigrum (9.85), B. pilosa (9.72) and S.acuta (8.10).Least colour strength was observed in case of dyed wool samples of $T$. procumbens (7.85)and P. histerophorus (7.44).

Leaves of lantana had been used for dyeing silk, wool and cotton along with metallic mordants such as copper sulphate and potassium dichromate with acceptable fastness properties (Dayalet al., 2006). Parthenium leaves have also been used for dyeing silk using synthetic mordants providing a wide range of soft, lustrous, dark and light colors (Suneeta and Mahale, 2002; Mathur and Srivastava, 2003).

Washing fastness of dyed fabric samples were recorded regarding colour change and colour staining. Slight colour change (4) was obtained in $T$. procumbens, $P$. histerophorus and A. adenophora dyed wool fabrics indicating very good wash fastness. Noticeable to slight colour change (3-4) was obtained in case of L.camara, S. nigrum, S. acutaand E.prostrate dyed fabric samples. Colour change was found noticeable (3) in case of $R$. nepalensis, E. bellidioides, G. diversifolia and $A$. vasica dyed wool fabric samples which implies good fastness. Among which colour of R.nepalensis and $G$. diversifolia dyed fabrics' colour changed to darker shade after washing fastness test which suggested more washing to be carried out soon after the dyeing. Considerable to noticeable (2-3) colour change was observed in I. cairica and B. pilosa dyed fabrics.

No colour staining (4-5) was observed in G. diversifolia, slight colour staining (4) was observed in case of $P$. histerophorus, $T$. procumbens and S. acuta and noticeable to slight colour staining (3-4) in L. camara, $S$. nigrum, A. adenophora, E. prostrate, E. bellidioides and $A$. vasica dyed wool samples. Noticeable colour staining was obtained in case of dyed wool samples of I. cairica and $R$. nepalensis dyes.

Rather et al., (2016) dyed wool with A. vasica extract, a natural dye and obtained beautiful color palette of shades of varied hue and tone by using metal salts (ferrous sulphate, alum and stannous chloride) and natural tannin extracts (gallnut, pomegranate peel and babool bark). Light fastness of the dyed fabrics ranged from poor to good. Table 1 depicts that moderate to good light fastness was exhibited by $T$. procumbens and $G$. diversifolia dyed fabrics.

Table 2 shows the dyeing properties of silk fabric dyed with different weed plants' extract. It is apparent from Table 2 that highest colour strength was obtained in case of $A$. adenophoradyed silk fabric(12.14) followed by fabric samples dyed with R.nepalensis (7.95), S.acuta (6.16), I.cairica (5.53), G. diversifolia (4.80), B.pilosa (4.75), E. bellidioides (4.72), L. camara (4.69), A. vasica (4.63), T. procumbens (4.61), P. histerophorus (4.24), S. nigrum (3.87) and E. prostrate (3.37).

Devi et al. (2002) used E. prostrate plant to develop 
Table 1. Colour properties of dyed wool fabric.

\begin{tabular}{|c|c|c|c|c|c|}
\hline \multirow{2}{*}{ Botanical name } & \multirow{2}{*}{ Common name } & \multirow{2}{*}{ Colour strength } & \multicolumn{2}{|c|}{ Wash fastness rating } & \multirow{2}{*}{$\begin{array}{l}\text { Light fast- } \\
\text { ness rating }\end{array}$} \\
\hline & & & Colour change & Colour staining & \\
\hline Lantana camara & Red sage & 11.35 & 3 & $3-4$ & 2 \\
\hline Solanum nigrum & Black night shade & 9.85 & $3-4$ & $3-4$ & 3 \\
\hline Tridaxprocumbens & Coat button & 7.85 & $3-4$ & 4 & $3-4$ \\
\hline Parthenium histerophorus & Carrot grass & 7.44 & $3-4$ & 4 & 2 \\
\hline Sidaacuta & Wireweed & 8.10 & $3-4$ & 4 & 2 \\
\hline Ipomeacairica & Cairo morning glory & 10.59 & $2-3$ & 3 & $2-3$ \\
\hline Rumexnepalensis & Nepal dock & 12.88 & 3 & 3 & 3 \\
\hline Ageratinaadenophora & Crofton weed & 21.55 & $3-4$ & $3-4$ & $3-4$ \\
\hline Ecliptaprostrata & False daisy & 10.47 & $3-4$ & $3-4$ & 2 \\
\hline Girardiniadiversifolia & Nilghiri nettle & 7.79 & 3 & $4-5$ & $4-5$ \\
\hline Erigeron bellidioides & Daisy fleabane & 11.17 & 3 & $3-4$ & 2 \\
\hline Bidenspilosa & Black jack & 9.72 & $2-3$ & $3-4$ & 3 \\
\hline Athatodavasica & Malabar nut & 11.25 & 3 & $3-4$ & 2 \\
\hline
\end{tabular}

Wash fastness rating: 1- Poor, 2- Fair, 3- Good, 4- Very Good, 5- Excellent; Light fastness rating:1- Very poor, 2- Poor, 3- Fair, 4- Moderate, 5- Good, 6- Very good, 7- Excellent, 8- Out standing

Table 2. Colour properties of dyed silk fabric.

\begin{tabular}{|c|c|c|c|c|c|}
\hline \multirow{2}{*}{ Botanical name } & \multirow{2}{*}{ Common name } & \multirow{2}{*}{$\begin{array}{l}\text { Colour } \\
\text { strength }\end{array}$} & \multicolumn{2}{|c|}{ Wash fastness rating } & \multirow{2}{*}{$\begin{array}{l}\text { Light fast- } \\
\text { ness rating }\end{array}$} \\
\hline & & & Colour change & Colour staining & \\
\hline Lantana camara & Red sage & 4.69 & $3-4$ & $3-4$ & 2 \\
\hline Solanum nigrum & Black night shade & 3.87 & 3 & $3-4$ & 2 \\
\hline Tridaxprocumbens & Coat button & 4.61 & $3-4$ & 4 & $3-4$ \\
\hline Parthenium histerophorus & Carrot grass & 4.24 & 4 & 4 & 2 \\
\hline Sidaacuta & Wireweed & 6.16 & 3 & 3 & 1 \\
\hline Ipomeacairica & Cairo morning glory & 5.53 & 3 & 3 & $2-3$ \\
\hline Rumexnepalensis & Nepal dock & 7.95 & $3-4$ & $3-4$ & 3 \\
\hline Ageratinaadenophora & Crofton weed & 12.14 & $3-4$ & $3-4$ & 3 \\
\hline Ecliptaprostrata & False daisy & 3.37 & 3 & $3-4$ & 2 \\
\hline G. diversifolia & Nilghiri nettle & 4.80 & $3-4$ & $4-5$ & $3-4$ \\
\hline Erigeron bellidioides & Daisy fleabane & 4.72 & 3 & 3 & 2 \\
\hline Bidenspilosa & Black jack & 4.75 & $3-4$ & $3-4$ & $2-3$ \\
\hline Athatodavasica & Malabar nut & 4.63 & $3-4$ & $3-4$ & 2 \\
\hline
\end{tabular}

Wash fastness rating: 1- Poor, 2- Fair, 3- Good, 4- Very Good, 5- Excellent; Light fastness rating:1- Very poor, 2- Poor, 3- Fair, 4- Moderate, 5- Good, 6- Very good, 7- Excellent, 8- Out standing

natural green shades on silk fabric.

The silk fabric samples dyed with different dye extracts exhibited washing fastness in range of good to very good. Slight colour change (4) was observed in case of $P$. histerophorus with slight staining in $T$. procumbens and $P$. histerophorus dyed silk fabric samples. Noticeable to slight colour change (3-4) was seen in case of L. camara, T. procumbens, $R$. nepalensis, $A$. adenophora, $G$. diversifolia, B. pilosa and $A$. vasica whereas slight to no colour staining was observed in $G$. diversifolia dyed silk fabric samples.

Noticeable to slight (3-4) colour staining was found in silk fabric samples dyed with L. camara, S. nigrum, $R$. nepalensis, A. adenophora, E. prostrate and A. vasica extracts. Wash fastness of silk fabric samples dyed with different plants was found to have noticeable colour change (3) in case of S. nigrum, S.acuta, I. cairica, $E$. prostrate and E. bellidioides extracts. Colour staining was observed as noticeable (3) in case of I. cairica,
S. acuta and E. bellidioides dyed silk fabric samples. Light fastness of silk fabric was similar to wool fabric. Value ranged from 1 to 4 where some plants exhibited poor light fastness and $G$. diversifolia showed excellent light fastness. Roots of $G$. diversifolia were used to dye pashmina fabric with brown and grey shades having excellent wash and good to very good light fastness properties by Kumar et al. (2015).

Moderate light fastness (3) was shown by $R$. nepalensis and $A$. adenophora extracts; in case of I. cairica and $B$. pilosa showed fair to moderate light fastness and fair rating of light fastness was exhibited by Lantana, solanum, parthenium, E. prostrate, E. bellidioides and $A$. vasica dyed silk fabric samples. Poor fastness was shown by $S$. acuta dyed silk fabric.

The increase in wash fastness with decreasing colour strength can be attributed to the fact that the less colour absorption by the fabric the less colour will come out during washing hence resulting high degree of wash 
fastness.

\section{Conclusion}

The dye extracts of someweed plants under study showed good colour strength but not so good fastness properties. Some fabric samples dyed in study showed fading of 1 rating whereas others exhibited remarkable light fastness property. Based upon these dyeability properties, some dye plants such as B. pilosa, G. diversifolia, $R$. nepalensis, A. adenophora, I. cairica and $T$. procumbens could be recommended for further studies. Different natural and synthetic mordants can be used to obtain varied range of hues and shades with acceptable fastness properties. Moreover other methods for enhancing colour strength and fastness properties can be further explored like plasma treatment and application of biomaterials like chitosan, etc.

\section{REFERENCES}

Annapurna, C. and Singh, J.S. (2003). Variation of Parthenium hysterophorus in response to soil quality: Implication for invasiveness. Weed Research, 43: 190-198.

Bansal, S. and Sood, A. (2001). Development of vegetable dye on cotton from Eupatorium leaves. Textile Magazine, 42(8): 81-84.

Chairat, M., Darumas, U., Bremner, J. and Bangrak, P. (2011). Dyeing of cotton yarn with the aqueous extract of the leaves of Eupatorium odoratum L. in Thailand and associated extract toxicity studies. Coloration Technology, 127(5):346 -353

Bhuyan, S. and Gogoi, N. J. (2013). A natural colourantValue addition of Eri silk yarns withDatura stramonium. Journal of Academic Industrial Research, 1(9): 530 -532 .

Dayal, R.,Dobhal, P.C., Kumar and Rawat, R. D. (2006). Natural dye from lantana camara leaves. Colourage, 53 (1):53-56.

Devi, A.S., Sumanthy,B. S. andKatyayini, V.K.T. (2002). Eclipta prostata - a weed rich in coloured pigments for silk. Man-Made Textiles in India, 45(5), 181-188.

Dumitrescu, E. I., Visileanu, E. E. and Niculescu, M. (2004). Natural dyes obtained from plants and vegetable wastes. Colourage Annual; 121-129

DWSR. (2013). Vision 2050. Directorate of Weed Science Research, Jabalpur, India.

Henriques, B. M.A. and Shankar, A. (2007). Natural dyeing for pollution free colouration of textiles by rural artisans and for revegetation of cultivable wastelands. Paper presented in stakeholders' workshop, ICEF Project on promotion of natural dyes in textile industries for environmental improvement and sustainable livelihood, Mumbai

Kala, C. P. (2002). Indigenous knowledge of Bhotiya tribal community on wool dyeing and its present status in the Garhwal Himalaya, India. Current Science, 83(7): 814817.

Kumar, A., Raja, A., Shakyawar, D. B., Pareek, P. K. and Krofa, D. (2015). Efficacy of natural dye from Gerardianadiversifolia on pashmina (Cashmere) shawls. Indian Journal of Fibre\& Textile Research, 40:180-183.

Kumaresan, M., Palanisamy, P. N. and Kumar, P. E. (2013).Comparison of fastness properties and colour strength of dyed cotton fabrics with ecofriendly natural dyes. The Experiment,8(3):483-489.

Mathur, M. and Srivastava, M. (2003). Natural dyes from Parthenium histerophorus: A study. Colourage,53 (12):53

Murty, P. and Venkaiah, M. (2011). Biodiversity of Weed Species in Crop Fields of North Coastal Andhra Pradesh, India. Indian Journal of Fundamental and Applied Life Science, 1 (2): 59-67

Negi, P.S. andHazra, P.K. (2007). Alien flora of Doon Valley, Northwest Himalaya. Current Science 92: 968-978.

Raghubanshi, A.S., Rai, L.C., Gaur, J.P. and Singh, J.S. (2005). Invasive alien species and biodiversity in India. Current Science, 88:539- 540.

Rather, L. J., Islam, S., Shabbir, M., Bukhari, M. N., Shahid, M., Khan, M. A. and Reddy, C.S. (2008). Catalogue of invasive alien flora of India. Life Science Journal, 5: 84 -89 .

Sachan, K. and Kapoor, V. P. (2007). Optimization of extraction and dyeing conditions for traditional turmeric dye, Indian Journal of Traditional Knowledge, 6 (2):270-278.

Sharma, A., Bansal, A. Rani, S. and Sood, A. (2007). An excellent natural dye source for Mulberry silk. Colourage, 54(1): 45-48.

Suneeta, M.B. and Mahale, G. (2002). Dye from parthenium leaves. Man-Made Textiles in India, 45(5): 198-200.

Tripathi, R.S., Singh, R.S. and Rai, J.P.N. (1981). Allelopathic potential of Eupatorium adenophorum - a dominant ruderal weed of Meghalaya. Proceedings of the Indian National Science Academy, Part B 47, 458-465

Trotman, E.R. (1993). Dyeing and chemical technology of textile fibres (6th Edition), ISBN 085264267 9, 254286, 511-527. 